\title{
Innovation management in the world under occidental dominance and in a new multi-polar world: a comparative perspective
}

\section{Jurgen Poesche*}

Aalto University, Department of Industrial Engineering and Management, P.O. Box 15500, 00076 Aalto, Finland

Email: jurgen.poesche@aalto.fi

*Corresponding author

\section{Barbara Igel}

Asian Institute of Technology,

School of Management,

P.O. Box 4, Khlong Luang, Pathumthani 12120, Thailand

Email: igel@ait.ac.th

\section{Ilkka Kauranen}

\author{
Aalto University, \\ Department of Industrial Engineering and Management, \\ P.O. Box 15500, 00076 Aalto, Finland \\ Email: ilkka.kauranen@aalto.fi
}

\begin{abstract}
This is a conceptual research study in the field of comparative management. For more than five centuries, the occident has been an economic, military, and cultural dominating force throughout the world, but now this long trend is reversing. Non-occidental countries are gaining momentum. China and India have become new world powers, anticipated to surpass the USA in economic might. The result will be global occidental dominance being replaced by a multi-polar world. The objective of this study is to conduct a comparison focusing on implications to innovation management - between the world under occidental dominance and the new multi-polar world. This approach is novel in comparative management. This study points out that multi-polarity will broaden the foundation for innovation, thus, giving rise to new and different innovation. Multi-polarity will enhance both the demand for and supply of innovation. An implication of multi-polarity for practice is that in multinational corporations operating in more than one major historical cultural sphere, it will be exceedingly difficult to maintain a uniform basis for the legitimation of innovation.
\end{abstract}

Keywords: comparative management; cognition; culture; diversity; innovation; legitimation; multi-polarity; occidental dominance.

Reference to this paper should be made as follows: Poesche, J., Igel, B. and Kauranen, I. (2019) 'Innovation management in the world under occidental dominance and in a new multi-polar world: a comparative perspective', Int. J. Comparative Management, Vol. 2, No. 1, pp.33-50. 
Biographical notes: Jurgen Poesche is a Visiting Researcher at the Aalto University, Department of Industrial Engineering and Management. He has earned doctoral degrees in business administration, law, and engineering. Apart from academia, he has worked in industry and consulting for 16 years. His latest industry position in industry was in corporate development. His research interests include corruption, engineering history, epistemology, innovation, multi-polarity and racism.

Barbara Igel is a Distinguished Adjunct Professor of Entrepreneurship and Innovation Management and former Dean of School of Management at the Asian Institute of Technology. She was also a Visiting Professor at the Helsinki University of Technology (now Aalto), Finland. Her research and teaching activities focus on technological innovation management and entrepreneurship in new ventures in Asia. She published over 60 papers in refereed academic journals, and serves as member in several editorial boards of reputed journals.

Ilkka Kauranen is a Professor of Development and Management in Industry at the Aalto University, Department of Industrial Engineering and Management. $\mathrm{He}$ is also a Distinguished Adjunct Professor at the Asian Institute of Technology. His research and teaching activities focus on research \& development management, co-engaging production, development of innovations, and entrepreneurship. He has published over 100 academic peer-reviewed journal articles, international conference papers, books, and other academic research reports. In addition to his academic career, he has vast experience in top management of companies and in management consulting.

\section{Introduction}

"Hear the other side" (Saint Augustine, born 354 AD, died 430 AD). The occident has not adhered to this advice of Saint Augustine.

Multi-polarity refers to a situation in which there are multiple centres of political influence or military power. The occident refers to the Western lands and regions. It comprises the countries of Europe and America. For more than five centuries, the occident has been an economic, military, and cultural dominating force throughout the world, but now this long-time trend is reversing. Non-occidental countries are gaining momentum. China and India have become new world powers, each expected to surpass the USA in economic might. In recent years, many other non-occidental countries, like Brazil, Congo, Ethiopia, Singapore, and Vietnam, have enjoyed higher growth rates than Western countries. The result will be that global occidental dominance will be replaced by a multi-polar world.

This is a conceptual research study in the field of comparative management. It addresses the changing macro dynamics of global economics driven by economic transitions, cultural changes and technology development. Comparative management means making comparisons between management practices in different contexts, for example between different countries or regions. In the present study, comparisons are made between the world under occidental dominance and the new multi-polar world. This approach is novel in comparative management. There have been several commendable contributions in comparative management and several broad analyses of the literature in this field in order to identify gaps in the extant literature. However, to our 
knowledge there has been no dedicated comparative study focusing on the consequences of the emergence of multi-polarity as result of the decline in the dominance of the occident (Aybar, 1991; Redding, 1994; Teagarden et al., 1995; Quah, 2011).

A result of the strengthening of the non-occident is that its global share of innovations, patents, and engineers is increasing at an accelerating speed (Veugelers, 2013). With the growing effect of non-occidental cognitions and cultures, the foundations of innovation will also change. This includes science and science-based engineering. As an illustration of the effect of cognition and cultures there is only one nature, but the interpretation of nature is dependent on cognition and culture, which are different in various parts of the world.

Studies on comparative management have emphasised the meaningful differences in the cognitive processes among people from different cultures (Adler et al., 1986; Redding, 1980). In contrast, according to Ross (2004), some researchers have gone too far in attributing importance to cognition and cultures. One way of doing this is by not sufficiently acknowledging that there are within-group differences in all cultures. Another way is to create artificial constructs that are unjustifiably aggregated across several individuals. As Bachelard (1972) has observed, science and the scientific method are the result of successes and mistakes made during their historical development. It would be more accurate to refer to different historical developments, each of which has taken place in their specific context in different parts of the world.

The acceptance of multi-polarity by occidental firms - including non-occidental firms operating within the confines of occidental cognition and culture - will be challenging. Losing a dominant position is a traumatic experience for individuals as well as for organisations. The change that the occident will be facing as a result of the emergence of multi-polarity will be more profound than any of the changes that have resulted from the long waves in economic activity (Rosenberg and Frischtak, 1984; Kitwood, 1986). The challenge of the occident commences in the view espoused in the occidental literature seeing non-occidental cognitions and cultures as problems to be overcome rather than opportunities (Kogut and Singh, 1988; Li et al., 2010, 2017). In a multi-polar world, differing cultures and worldviews among groups can lead to conflicts over competing values and behaviours. Innovative search (Martini et al., 2017), organisation climate (Bowen and Ostroff, 2004) and collective norms (Luo and Ho, 2001; Gao et al., 2017) are among multiple factors related to innovation that are unfavourably affected by occidental views of non-occidental foundations of innovation.

Whereas, legitimation is a social process (Suchman, 1995; Bitektine and Haack, 2015), the acceptance of multi-polarity and innovation founded on non-occidental foundations are a social issue and ultimately a societal issue. Society plays a predominant role in legitimation (Chevalier, 1986; Wallerstein, 2012). A related issue is that innovation contravening valid societal institutions is not considered legitimate (Kooijman et al., 2017).

In the context of multi-polarity, Miles' (2010) view that a 'cultural lag' prevents societies from staying abreast with 'technological change' gets another meaning. The 'cultural lag' is not within occidental society, but it is between occidental and non-occidental societies. The 'cultural lag' is not something non-occidental societies should attempt to bridge by abandoning their views on legitimation because the perceived 'cultural lag' in this context is a different foundation for innovation. Both the occident 
and the non-occident can benefit from a wider range of foundations for innovation as it enhances innovation.

A broad array of definitions has been put forward for innovation (Merriam-Webster, 2018; ft.com/lexicon, 2018; Business Dictionary, 2018; Edison et al., 2014). Among others, Baregheh et al. (2009) have acknowledged the need to identify one integrative, multi-disciplinary definition of innovation. Based on their widely cited literature study with a content analysis of previous definitions of innovation Baregheh et al. (2009, p.1334) suggest this definition: "Innovation is the multi-stage process whereby organizations transform ideas into new/improved products, service or processes, in order to advance, compete and differentiate themselves successfully in their marketplace".

Important in the definition of innovation is the prerequisite that, in order to qualify as an innovation, success in the marketplace has to be achieved. Success in this context can mean products or services that fulfil the needs of customers but it can also mean success by the fact that value is added to the society at large by the adoption of something new and effective. This characteristic also differentiates innovation from invention. Invention refers to developing something new to the world; but an invention does not need to penetrate into the society by means of adoption (Key Differences, 2018; CPI, 2018).

Innovation may require capital investments, thus, inducing risks associated with capital investments. When risks have been assessed in the literature, the focus has been on exchange rates, and institutional and market issues (Tong and Reuer, 2007; Chung et al., 2010; Song, 2017). This refers to risks that are associated with the decline in the occidental dominance and risks that are associated with the strengthening of nonoccidental cognitions and cultures.

The objective of this study is to conduct a comparison - focusing on implications to innovation management - between the world under occidental dominance and the new multi-polar world. The comparisons in this study have important messages for the occident. Non-occidental countries are gaining comparative strength. A multi-polar world is emerging. These are compelling reasons for the occident to hear the other side, the non-occident.

The rest of the article is structured as follows: first, multi-polarity is discussed from a general perspective. It is noted how humanity gives rise to multi-polarity. The background for the comparison of the occident and the non-occident is described. Second, legitimation is a challenge to multi-polarity. Third, in this article with its focus on implications for innovation management, and thus, an in-depth comparison of legitimation of innovation in the world under occidental dominance and in the new multi-polar world is warranted. A central theme of the article is how multi-polarity broadens the foundation of innovation. A broader foundation of innovation enhances both the supply of innovation and the demand for innovation. This is discussed in a comparative manner. Finally, the contributions of the study are listed and avenues for further study are proposed in the conclusion part.

\section{Multi-polar world}

Humanity is diverse and this gives rise to multi-polarity. The diversity manifests itself in cognitive and cultural differences. One of the expressions of multi-polarity is the historical cultural spheres found around the world, some of which are shown in Figure 1. 
Figure 1 Some major historical cultural spheres

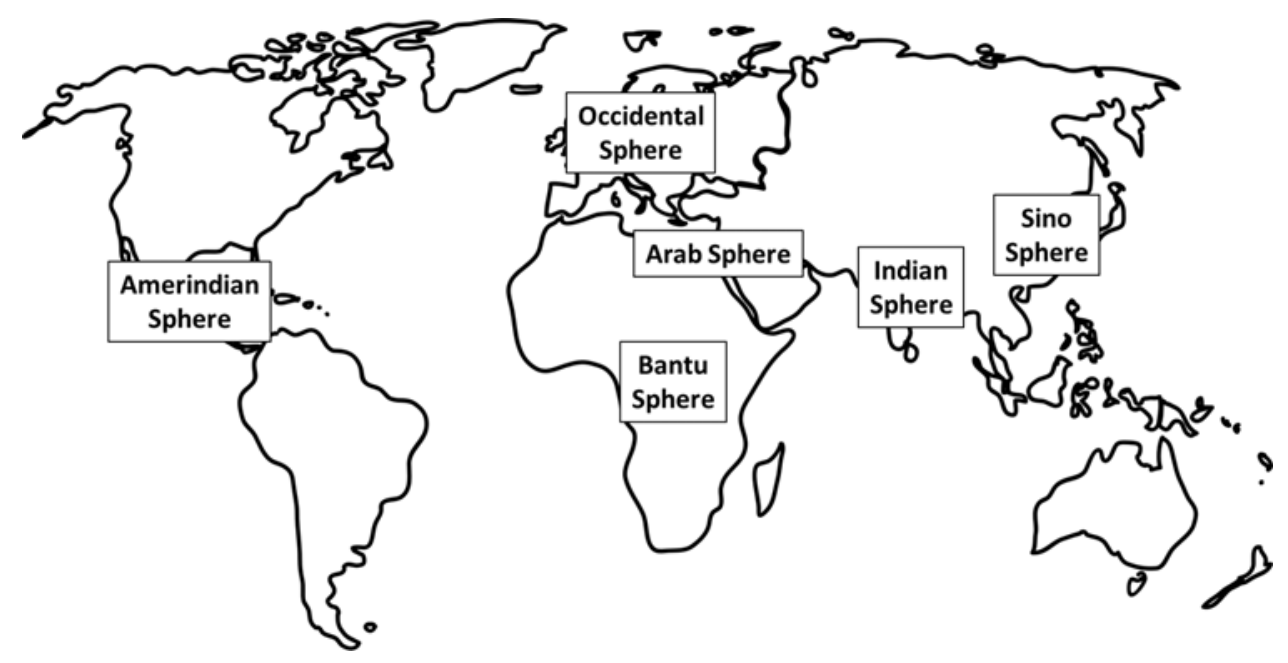

Source: This figure is based on Poesche et al. (2017)

Multi-polarity has been considered in the context of political entities (countries), e.g., David (2013) and Roy (2014), but the cognitive and cultural differences associated with multi-polarity do not always correspond to political boundaries (López-Duarte et al., 2016): there may be more than one major historical culture within one country, and there may be significant uniformity stretching several countries. Whereas, diversity is a result of historical developments, one way to identify major cultural spheres is historical (Witchalls, 2012).

Humanity is globally the same while at the same time it is also culturally diverse (Iribarne, 2008). Sociocultural diversity has been claimed to interrelate with demographic diversity (Ely and Thomas, 2001; Munongo, 2011), but this claim is problematic if demographic subgroups are cognitively and culturally similar. Multi-polarity is about sociocultural diversity that results in cognitive and cultural diversity. There have been attempts to broaden the cognitive and cultural foundation in management (Prieto-Carrón et al., 2006).

Multi-polarity is characterised by the existence of several poles of power, but the foundation of the power is not the same in every major cultural sphere (Courmont and Mottet, 2013). Over time, the power of various historical cultural spheres has fluctuated. After the late 15th century, particularly the military power of the occident commenced to grow, and the occident projected its power worldwide. For the last two centuries, the occident has been globally dominant, and this has translated into the global dominance of Occidental cognition and culture - a dominance that is borne out in, e.g., Borim-de-Souza et al. (2018). Occidental engineering and science are products of occidental cognition and culture. As part of occidental might, occidental engineering-based and science-based innovation have dominated globally.

Figure 2 outlines changes in the global relative weight of different cultural spheres. Over time (horizontal axis), the trend of an increasing global dominance of occidental cognition and culture has resulted in a reduction of the relative weight (represented by the vertical width) of non-occidental cultural spheres. If history can be relied on as a guide, no dominance is permanent: the once dominant Teotihuacan fell, as did the Carthaginian, 
Mughal, and Roman Empires. From the standpoint of innovation, the issue is whether the non-occidental major cultural spheres are on the cusp of experiencing a renaissance that will result in innovation based on non-occidental cognition and cultures.

Figure 2 Over time (horizontal axis), the trend of an increasing global dominance of occidental cognition and culture has resulted in a reduction of the relative weight (represented by the vertical width) of non-occidental cultural spheres

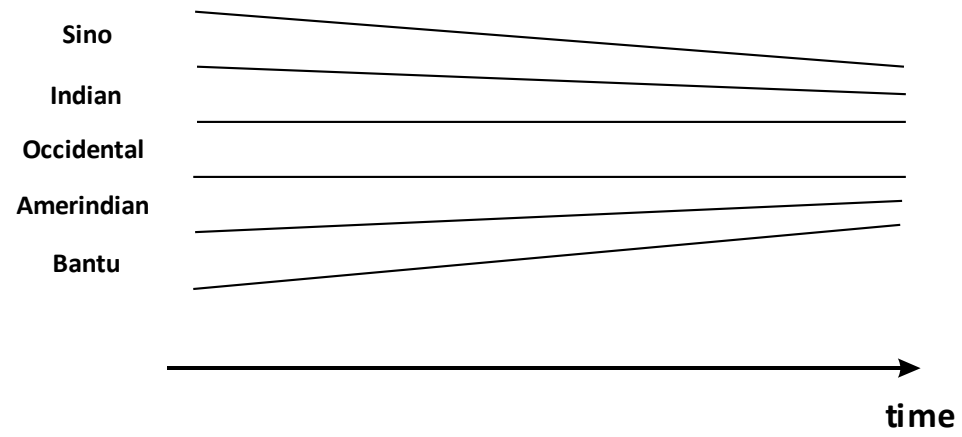

Income inequality has been deemed to be caused by obstacles to competition (Berger, 2004). In parallel, when comparing the occident and the non-occident, the inequality caused by occidental dominance can be considered to be a result of the lack of innovation-based competition between different cognitive and cultural foundations. The inequality between occidental and non-occidental cognitions and cultures has not been a natural phenomenon in the last centuries - as little as social inequality is a natural phenomenon (Berger, 2004). One of the reasons for the inequality has been that alternatives to occidental cognition and culture have been impeded in their development as a result of occidental colonialism. The result has been that alternative engineering, innovation, and science that are founded on different non-occidental cognitions and cultures have had too little resources. The growing resources, particularly in the Indian and Sino major cultural spheres, suggest that a renaissance of non-occidental cognitions and cultures - and innovation based on them - is evident.

Decolonisation has not meant the end of occidental dominance over the non-occident. Occidental influence has found new avenues, or some old patterns have continued and even proliferated. At the government level, the major international treaties regulating international trade are invariably founded on occidental legal concepts, and thus they are products of occidental cognition and culture (Fainshmidt et al., 2014). This affects innovation directly when such treaties cover intellectual property rights. Although nominally neutral, underpinning the intellectual property right protections is the assumption that occidental innovation and inventions need to be protected (Dong and Flowers, 2016), thus, implicitly manifesting occidental cognitive and cultural supremacy.

At the firm level, the scholarly literature on international management contains the finding that firms often implement certain specific management processes (Wilkinson et al., 2008; Varma, 2009). This contains the usually implicit message of the supremacy of the currently dominant occident, because almost all multinational enterprises have been Occidental until recently. This issue is exacerbated by some of the scholarly literature on international management. Such studies have pointed out that in the firms that have been observed occidental management processes are dominant but these studies 
have not pointed out that all countries that have been observed in the study are cognitively and culturally closely related.

In international comparisons concerning management, it is warranted to point out that the organisational foundations of multi-polarity are not necessarily the current large multinational firms. Jackson et al. (2008) have observed that local non-occidental cognitions and cultures can typically be found in the smallest firms, but the larger firms are commonly 'occidentalised'. The aggressive globalisation of non-occidental firms observed by, among others, Yadong and Tung (2007) and Bangara et al. (2012) does not contribute to multi-polarity, if these firms adopt occidental cognition and culture. In such cases, it is characteristic that occidental concepts have been adopted (Jackson et al., 2008; Darawong and Igel, 2012).

Comparing the occident and the non-occident reveals that along with the strengthening of non-occidental major cultural spheres, the cognitive and cultural foundations of what is perceived legitimate is shifting. This development can even lead to the loss of legitimacy for firms and thus should be given more attention, as pointed out by Capron (2005).

Brondoni (2012) has emphasised that innovative firms should operate under conditions of multi-polarity with technological multi-polar clusters where personnel with different backgrounds and skills collaborate. There is abundant evidence that cognitive and cultural diversity is a valuable resource in innovation, and unconventional research and development have been found to be especially conducive to innovation (Wan et al., 2015; Østergaard et al., 2011; van Knippenberg and Mell, 2016; van Beers and Xand, 2014; Bassett-Jones, 2005). Consequently, the diversity resulting from the differences between the occident and the non-occident should be seen as an asset. Furthermore, this development that is enabling more diversity is rapidly strengthening (Ting-Toomey et al., 1991; Jassawalla et al., 2004; Darawong et al., 2016). The population is growing faster in the non-occident than in the occident. Already about half of the world's population live in the economically dynamic Indian and Sino cultural spheres alone. Commendable attempts have been made in order to develop new frameworks in the quest for cultural understanding (Keating and Abramson, 2009).

In the context of emerging multi-polarity, the finding of Ballet and Bazin (2008) that diminished flexibility embodies a problem for a firm is important, but this line of thinking needs to be expanded. The issue is broader than the ending of a path in the context of path-dependency identified by Beyer (2005). It is not solely about a new path on an island representing occidental cognition and culture, but exploring without preconceived ideas unknown islands representing non-occidental cognitions and cultures.

\section{Legitimation of innovation}

Legitimation is a challenge for multi-polarity. There has been a strong occidental bias in the literature, but more and more studies with non-occidental perspectives are emerging (López-Duarte et al., 2016; Bangara et al., 2012). Legitimation is a social process (Suchman, 1995; Bitektine and Haack, 2015). The literature on legitimation has been founded on the occidental developed economies. It cannot be assumed that the occidental literature is valid for non-occidental economies (Boisot and Child, 1996; Ahlstrom et al., 2008). The occidental dominance in literature has not been broken - at least - yet 
although Hong and Chiu (2001) highlighted this issue almost two decades ago. This occidental bias carries over to legitimation of the foundation of corporate social responsibility (Jamali et al., 2017).

A frequently used definition of legitimation in strategic management has been given by Suchman (1995, p.574): legitimation is "a generalized perception or assumption that the actions of an entity are desirable, proper, or appropriate within the socially constructed system of norms, values, beliefs, and definitions." The term socially is ambiguous. In the strategic management literature, there has been a tendency to consider that firms are able to create their own foundations of legitimation (Aldrich and Fiol, 1994; Bitektine and Haack, 2015; Binz et al., 2016). Kostova and Zaheer (1999) have put forward that legitimation in a multinational firm can be viewed either at the level of the entire firm or at the level of different national subsidiaries of the same firm. This viewpoint gives credit to the importance of influences from outside the firm. In addition, this viewpoint emphasises cognitive and cultural diversity between major historical cultural spheres. Furthermore, Bitektine and Haack (2015) and Johnson et al. (2006) have pointed out that legitimacy is assessed by external evaluators and the behaviour of firms is strongly affected by external institutions. Looking beyond the strategic management literature, a problem remains: according to Habermas (2012), the function of legitimation is the avoidance of chaos. A firm operating in a multi-polar world needs to find a way to avoid chaos internally (i.e., between its operations in different major historical cultural spheres) and externally (i.e., between its subsidiary and the major historical cultural sphere the subsidiary operates in). With the emergence of multi-polarity, occidental dominance cannot take on the role of mitigating such clashes in the future.

Legitimation can be considered to be founded on cognition or discourse (Suchman, 1995; Suddaby and Greenwood, 2005; Vaara and Tienari, 2008), and both occur in the context of society. Society plays a decisive role in legitimation (Chevalier, 1986; Wallerstein, 2012). Menkes (1980) has continued this line of thinking by arguing that legitimation is neither individual nor particularistic. It is therefore highly questionable to assume that legitimation can occur in and by firms, i.e., independent of society.

Legitimation should not be confused with legality (Kennedy and Adams, 1986; Vergara et al., 2006). The view expressed by Suárez (2006) - that there are situations in which there are conflicts between cognition and legitimation - might be interpreted as problematic for the interrelationship between cognition and legitimation via society. In such situations of conflict, firms may attempt legitimation using criteria considered illegitimate by society. With the emergence of multi-polarity and firms accustomed to occidental dominance, this issue will probably become more acute in the coming years. In the same way as firms have reorganised their internal operations to remain legitimate or regain legitimacy in the past (DiMaggio and Powell, 1983; Singh et al., 1986), in the future it will be necessary for firms to reorganise their operations to comply with the requirements of multi-polarity. The latter challenge can be much greater.

Keeping in mind that innovation is often based on engineering - the view that legitimation consists of an interplay between engineering and society expressed by, e.g., Geels (2002) warrants attention. In the past, occidental dominance has meant that the legitimation of processes and products based on occidental engineering has been founded on occidental cognition and culture. The emergence of multi-polarity will require that in the co-existence of occidental engineering and non-occidental countries, the processes and products rooted in occidental engineering need to comply with the requirements of non-Occidental cognitions and cultures, too. In the interaction of legitimation and 
competition associated with innovation processes (Geroski, 2000), the requirements of non-occidental cognitions and cultures need to be taken into account as well.

In the course of the selection of innovation projects and innovation processes, forecasts have to be made. As Robinson (1988) has observed, there are contradictions in legitimation and socioeconomic forecasting. When to this is added Robinson's (1992) view that the perceived neutrality and objectivity of socioeconomic models are used to legitimise policy, it is warranted to ask whether forecasting is used to legitimise a preconceived idea, e.g., a continued occidental dominance.

The emergence of multi-polarity - and the associated cognitive and cultural diversity - raises the issue of the relative position of legitimation and society. The occidental dominance of at least two centuries reduced conflicts between legitimation and society. The emergence of multi-polarity makes it necessary to establish a hierarchy between legitimation and society, a hierarchy that puts society as the source of cognition and culture above legitimation.

\section{Multi-polarity and innovation: broadening the foundation}

By mobilising non-occidental cognitions and cultures, in addition to occidental cognition and culture, multi-polarity broadens the cognitive and cultural foundation of innovation as shown in Figure 3.

Figure 3 Multi-polarity broadens the foundation for innovation

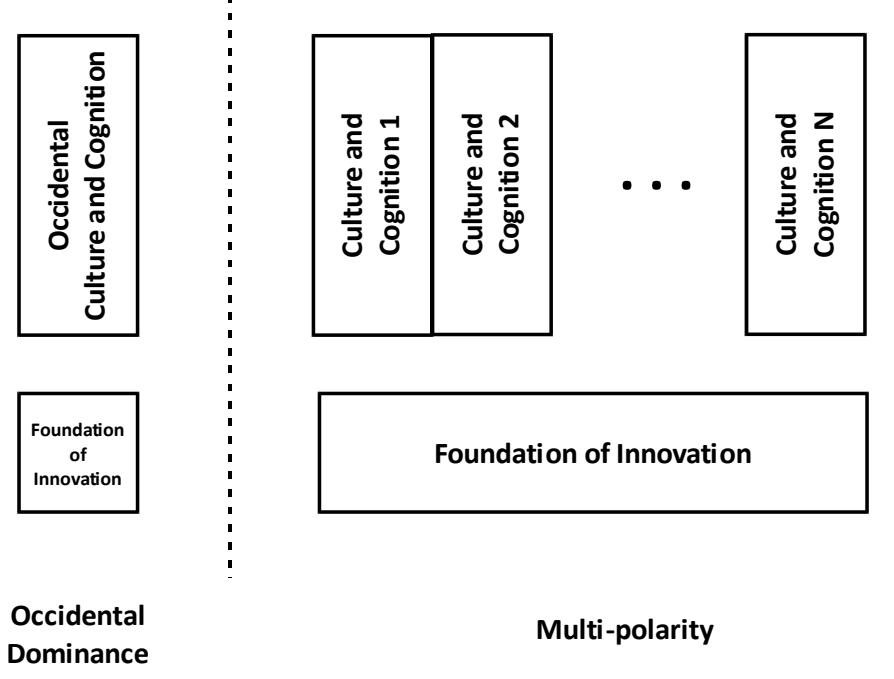

Notes: During the time of occidental dominance, the foundation of innovation was based only on occidental culture and cognition. In a multi-polar world, the foundation of innovation is based on many parallel cultures and cognitions.

Source: This figure is based on Poesche et al. (2017)

Knowledge in engineering and science that forms the foundation of innovation is a product of the cognition and culture prevalent in the society in question. The relevant 
cognition and culture do not only influence past and present knowledge, they also influence future knowledge, for example, by affecting the questions to which answers are sought.

Martini et al. (2017) have argued that innovation depends on the search, generation, synthesis, and integration of knowledge. One of the drivers of international diversification has officially been to enhance access to different kinds of knowledge (Dunning, 1979; Oladottir et al., 2012). An important issue is what constrains the search of knowledge. If the search for knowledge is constrained by occidental cognition and culture, then the answers congruent with non-occidental cognitions and cultures are partly or totally out of reach. This point is obvious from history and it works both ways. For example, in their extensive studies, Sulvarán López and Ávila Romero (2014) have given ample evidence of cases in which knowledge that has not been congruent with the occidental cognition and culture has been rejected by the occident. An extreme case of this is the fate of indigenous knowledge in the USA. These cases illustrate how multi-polarity broadens the foundation of innovation.

Within firms, the organisational climate can constrain the adoption and search for knowledge founded on non-occidental cognitions and cultures. Bowen and Ostroff (2004, p.205) have defined organisational climate as "a shared perception of what the organization is like in terms of practices, policies, procedures, routines, and rewards what is important and what behaviors are expected and rewarded." From the standpoint of multi-polarity, a central issue is the cognitive and cultural foundation of the expected and rewarded behaviours. If the explicit or even implicit expectation is that knowledge confined by occidental cognition and science is superior to its alternatives, then the foundation of innovation is narrowed. Besides, there are no grounds for such explicit or implicit expectations.

Organisational climate has been divided into strategic goals and values (Parke and Seo, 2017). Both are impacted by society, because the relevant cognition and culture defines what is considered acceptable behaviour in the society in question. A counterargument would be that, in the course of the globalisation that has occurred during the last three decades, occidental concepts have been implemented in non-occidental countries irrespective of their legitimacy in these countries. It would be inaccurate to conclude from this that occidental concepts are considered legitimate. Rather, this may be a case of tolerating something illegitimate, maybe under perceived duress.

Although diversity is consciously considered in the context of strategic management and innovation (Schotter et al., 2017), this does not mean that diversity is considered an asset. A problem with the strategic management and innovation literature is that the cognitive and cultural foundations of innovation have received only little attention. Surprisingly, even if bicultural individuals in senior positions of multinational firms have striven to support contributions from non-occidental countries (Kane and Levina, 2017), the resulting contributions often have not been founded on non-occidental cognitions and cultures. Similar observations have been made concerning occidental multinational corporations with significant resources (Birkinshaw et al., 2017). Subsidiaries of these corporations in non-occidental countries often rely solely or to a great degree on resources founded on occidental cognitions and cultures. Even if geographical fragmentation of industries can be observed (Chang, 1995; Pietrobelli and Puppato, 2016; Yang et al., 2017; Ado et al., 2017), cognitive and cultural diversity is often scant.

A related challenge is that firms are straddling two contradictory demands: navigating a strategic balance between the demands for conformity and for differentiation (Zhao 
et al., 2017). During the occidental dominance, the demand for conformity has meant that the firms have adopted and sought knowledge founded on occidental cognition and culture. Although this has allowed for some differentiation, this differentiation has been within the confines of occidental cognition and culture. Multi-polarity will broaden differentiation opportunities, but these opportunities may be difficult to reconcile with the demand for conformity with occidental cognition and culture, particularly in occidental firms.

Figure 4 Multi-polarity impacts both the demand for innovation and the supply of innovation

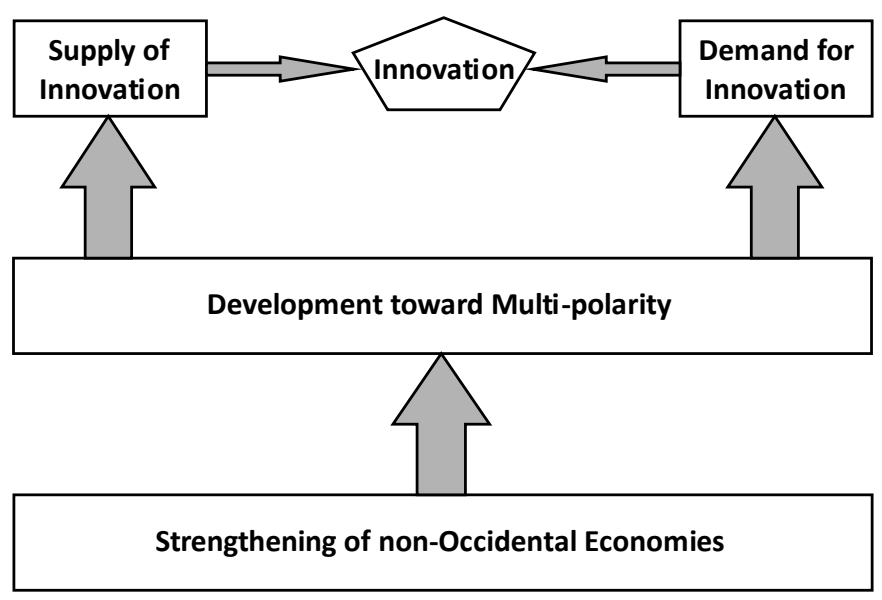

Achieving economies of scale associated with market power and operational efficiency has benefitted from the occidental dominance. Because of the limited market size in non-occidental countries, production facilities have effectively been forced to adhere to knowledge congruent with occidental cognition and culture. The raison d'être of multinational corporations has been seen in market power and efficiency effects (Clougherty et al., 2017). The strengthening of non-occidental economies will change this dynamics. In the coming years, economies of scale may be achieved by adhering to non-occidental cognitions and cultures in major historical cultural spheres outside of the occident. As Figure 4 shows, multi-polarity impacts both the demand for and supply of innovation. The increasing wealth in non-occidental societies associated with multi-polarity creates demand for products and services congruent with non-occidental cognitions and cultures on the one hand, and provides resources for research and development activities resulting in products and services congruent with non-occidental cognitions and cultures on the other hand.

The engineering, scientific and other concepts adopted by a firm may be considered to be institutions. Institutional theory offers an explanation for why institutionalisation leads to a situation in which collective norms, as they relate to, e.g., markets, supersede a firm's competences (Luo and Ho, 2001; Gao et al., 2017). Ahmadi et al. (2017) have identified several mechanisms by which intra-firm regulations, in a similar vein, impact innovation development. Under the occidental dominance, non-occidental firms have had to institutionalise concepts founded on occidental cognition and culture. Simultaneously, institutions have forced non-occidental firms to adopt concepts congruent with occidental cognition and culture. 
The development of information and communications technology (ICT) enhances the mobilisation of non-occidental knowledge, which to a great degree is not easily accessible. Much of non-occidental knowledge is imbedded in oral traditions in disadvantaged and remote societies. Its very survival may have been the result of limited contacts with occidental cognition and culture. In such cases, intensifying contacts may be detrimental to the survival and development of non-occidental knowledge, and thus, corresponding innovation. It remains to be seen whether the global cultural changes caused by ICT (Roy, 2014) will result in a proliferation of occidental dominance over some timeframe, or whether these changes will favour multi-polarity.

\section{Conclusions}

This is a conceptual research study in the field of comparative management. It addresses the changing macro dynamics of global economics driven by economic transitions, cultural changes and technology development. The objective of this study is to conduct a comparison - focusing on implications to innovation management - between the world under occidental dominance and the new multi-polar world. The multi-polarity argument requires that the usually implicit assumptions leading to an occidental bias in the strategic management and innovation literature are identified. The paper's contributions are:

1 Multi-polar world: the strengthening of non-occidental countries will result in innovation founded on and being congruent with non-occidental cognitions and cultures. The current global occidental dominance will be reduced as a consequence. The result will be multi-polarity in the cognitive and cultural foundations of innovation.

2 Legitimation: legitimation is a social phenomenon. Intrafirm legitimation has to be congruent with what is considered legitimate by society, and ultimately it needs to be in agreement with the cognition and culture prevalent in the relevant society. The fact that occidental concepts have been tolerated in the non-occident does not prove that their legitimacy in non-occidental countries will continue.

3 Multi-polarity and innovation: an implication of multi-polarity to practice is that it will give rise to new and different innovation. This is because multi-polarity will broaden the foundation for innovation and because multi-polarity will enhance both the demand for and supply of innovation.

4 Multinational corporations and multi-polarity: an implication of multi-polarity for management practice is that in multinational corporations operating in more than one major historical cultural sphere, it will be exceedingly difficult to maintain a uniform basis for legitimation of innovation. Management in multinational corporations need to cultivate multi-polarity within their organisations by listening to the various local cultures.

\section{Further research is required in:}

1 Pace of the emergence of multi-polarity: in strategic management, one of the biggest challenges is forecasting the pace of change. The emergence of multi-polarity is no 
different. Complicating the matter is that the emergence of multi-polarity will probably unfold an accelerating dynamic once it has commenced.

2 Empirical cases: whereas, this paper is conceptual, it does not contain empirical cases. Studies of empirical cases would deepen the understanding of the emerging multi-polarity in innovation. Comparative empirical studies between different major historical cultural spheres would allow an identification of differences in the dynamics toward multi-polarity in the various major historical cultural spheres.

With the emergence of multi-polarity, the global dominance of the occident will weaken. At the same time, this means that the foundation of innovation will broaden. The Occident will be able to benefit in innovation development from knowledge founded on non-Occidental cognitions and cultures. The time has come to take the 1,600-year-old advice of Saint Augustine: "Hear the other side."

\section{References}

Adler, N.J., Doktor, R. and Redding G.S. (1986) 'From the Atlantic to the Pacific century: cross-cultural management reviewed', Journal of Management, Vol. 2, No. 12, pp.295-318.

Ado, A., Su, Z. and Wanjiru, R. (2017) 'Learning and knowledge transfer in Africa-China JVs: interplay between informalities, culture, and social capital', Journal of International Management, Vol. 23, No. 2, pp.166-179.

Ahlstrom, D., Bruton, G.D. and Yeh, K.S. (2008) 'Private firms in China: building legitimacy in an emerging economy', Journal of World Business, Vol. 43, No. 4, pp.385-399.

Ahmadi, S., Khanagha, S., Berchicci, L. and Jansen, J.J.P. (2017) 'Are managers motivated to explore in the face of a new technological change? The role of regulatory focus, fit, and complexity of decision-making', Journal of Management Studies, Vol. 54, No. 2, pp.209-237.

Aldrich, H.E. and Fiol, C.M. (1994) 'Fools rush in? The institutional context of industry creation', Academy of Management Review, Vol. 19, No. 4, pp.645-670.

Aybar, C.B. (1991) 'A review of comparative management theory \& methodology', Istanbul Universitesi Isletme Fakultesi Dergisi, Vol. 20, Nos. 1-2, pp.67-80.

Bachelard, G. (1972) L'Engagement Rationaliste, Presses Universitaires de France, Paris, France.

Ballet, J. and Bazin, D. (2008) 'Le management responsible comme modèle de gestion de l'obsolescence morale : responsabilité, identité et capital symbolique', Revue des Sciences de Gestion, Direction et Gestion, Vol. 43, Nos. 231-232, pp.165-168.

Bangara, A., Freeman, S. and Schroder, W. (2012) 'Legitimacy and accelerated internationalisation: an Indian perspective', Journal of World Business, Vol. 47, No. 4, pp.623-634.

Baregheh, A., Rowley, J. and Sambrook, S. (2009) 'Towards a multidisciplinary definition of innovation', Management Decision, Vol. 47, No. 8, pp.1323-1339.

Bassett-Jones, N. (2005) 'The paradox of diversity management, creativity and innovation', Creativity and Innovation Management, Vol. 14, No. 2, pp.169-175.

Berger, J. (2004) 'Über den ursprung der ungleichheit unter den menschen', Zeitschrift für Soziologie, Vol. 33, No. 5, pp.354-374.

Beyer, J. (2005) 'Pfadabhängigkeit ist nicht gleich Pfadabhängigkeit! Wider den impliziten konservatismus eines gängigen konzepts', Zeitschrift für Soziologie, Vol. 34, No. 1, pp.5-21.

Binz, C., Harris-Lovett, S., Kiparsky, M., Sedlak, D.L. and Truffer, B. (2016) 'The thorny road to technology legitimation - institutional work for potable water reuse in California', Technological Forecasting and Social Change, Vol. 103, No. 1, pp.249-263. 
Birkinshaw, J., Ambos, T.C. and Bouquet, C. (2017) 'Boundary spanning activities of corporate HQ executives' insights from a longitudinal study', Journal of Management Studies, Vol. 54, No. 4, pp.422-454.

Bitektine, A. and Hack, P. (2015) 'The 'macro' and the 'micro' of legitimacy: toward a multilevel theory of the legitimacy process', Academy of Management Review, Vol. 40, No. 1, pp.49-75.

Boisot, M. and Child, J. (1996) 'From fiefs to clans and network capitalism: explaining China's emerging economic order', Administrative Science Quarterly, Vol. 41, No. 4, pp.600-628.

Borim-de-Souza, R., Woitas, N.M.A., Zanoni, B.L. and Chiba, J.H.F. (2018) 'Internationalisation and sustainability as a field: a contingent view of comparative management via Bourdieusian sociology', International Journal of Comparative Management, Vol. 1, No. 1, pp.26-44.

Bowen, D.E. and Ostroff, C. (2004) 'Understanding HRM-firm performance linkages: the role of the 'strength' of the HRM system', Academy of Management Review, Vol. 29, No. 2, pp.203-221.

Brondoni, S.M. (2012) 'Ouverture de 'innovation management in global markets (1)', Symphonya, Vol. 12, No. 1, pp.1-9.

Business Dictionary (2018) Innovation [online] www.businessdictionary.com/definition/ innovation.html (accessed 7 July 2018).

Capron, M. (2005) 'Les nouvelles responsabilités sociétales des entreprises: de quelles «nouveautés» s'agit-il ?', Revue des Sciences de Gestion, Direction et Gestion, Vol. 40, Nos. 211-212, pp.47-54.

Chang, S.J. (1995) 'International expansion strategy of Japanese firms: capability building through sequential entry', Academy of Management Journal, Vol. 38, No. 2, pp.383-407.

Chevalier, G. (1986) 'Parasciences et procédés de legitimation', Revue Française de Sociologie, Vol. 27, No. 2, pp.205-219.

Chung, C.C., Lee, S-H., Beamish, P.W. and Isobe, T. (2010) 'Subsidiary expansion/contraction during times of economic crisis', Journal of International Business Studies, Vol. 41, No. 3 , pp.500-516.

Clougherty, J.A., Kim, J.U., Skousen, B.R. and Szücs, F. (2017) 'The foundations of international business: cross-border investment activity and the balance between market power and efficiency effects', Journal of Management Studies, Vol. 54, No. 3, pp.340-365.

Courmont, B. and Mottet, É. (2013) 'La multipolarité : pour quoi faire ?', in Courmont, B. and Mottet, É. (Eds.): Repenser la Multipolarité, pp.15-34, Septentrion, Québec, QC.

CPI (2018) The Difference Between Invention and Innovation [online] www.uk-cpi.com/blog/thedifference-between-invention-and-innovation (accessed 7 July 2018).

Darawong, C. and Igel, B. (2012) 'Acculturation of local new product development team members in MNC subsidiaries in Thailand', Asia Pacific Journal of Marketing and Logistics, Vol. 24, No. 3, pp.351-371.

Darawong, C., Igel, B. and Badir, Y.F. (2016) 'The impact of communication on conflict between expatriate and local NPD managers of MNC Subsidiaries in Thailand: a local perspective', Journal of Asia Pacific Business, Vol. 17, No. 1, pp.81-99.

David, C-P. (2013) 'Vers une monde uni-multipolaire ?', in Courmont, B. and Mottet, É. (Eds.): Repenser la Multipolarité, pp.407-414, Septentrion, Québec, QC.

DiMaggio, P.J. and Powell, W.W. (1983) 'The iron cage revisited: institutional isomorphism and collective rationality in organizational fields', American Sociological Review, Vol. 48, No. 2, pp.147-160.

Dong, M. and Flowers, S. (2016) 'Exploring innovation in Shanzhai: the case of mobile phones', Asian Journal of Technology Innovation, Vol. 24, No. 2, pp.234-253.

Dunning, J.H. (1979) 'Explaining patterns of international production: in defense of the eclectic theory', Oxford Bulletin of Economics and Statistics, Vol. 41, No. 3, pp.269-295.

Edison, H., Ali, N.B. and Torkar, R. (2014) 'Towards innovation measurement in the software industry', Journal of Systems and Software, Vol. 86, No. 5, pp.1390-407. 
Ely, R.J. and Thomas, D.A. (2001) 'Cultural diversity at work: the effects of diversity perspectives on work group processes and outcomes', Administrative Science Quarterly, Vol. 46, No. 2, pp.229-273.

Fainshmidt, S., White, G.O. and Cangioni, C. (2014) 'Legal distance, cognitive distance, and conflict resolution in international business intellectual property disputes', Journal of International Management, Vol. 20, No. 2, pp.188-200.

ft.com/lexicon (2018) Definition of Innovation [online] www.Lexicon.ft.com/Term?term= innovation (accessed 7 July 2018).

Gao, Y., Shu, C., Jiang, X., Gao, S. and Page, A.L. (2017) 'Managerial ties and product innovation: the moderating roles of macro- and micro-institutional environments', Long Range Planning, Vol. 50, No. 2, pp.168-183.

Geels, F.W. (2002) 'Technological transitions as evolutionary reconfiguration processes: a multi-level perspective and a case-study', Research Policy, Vol. 31, Nos. 8-9, pp.1257-1274.

Geroski, P.A. (2000) 'Models of technology diffusion', Research Policy, Vol. 29, Nos. 4-5, pp.603-625.

Habermas, J. (2012) Raison et Légitimité: Problèmes de Légitimation Dans le Capitalisme Avancé, Payot \& Rivages, Paris, France.

Hong, Y-Y. and Chiu, C-Y. (2001) 'Toward a paradigm shift: from cross-cultural differences in social cognition to social-cognitive mediation of cultural differences', Social Cognition, Vol. 19, No. 3, pp.181-196.

Iribarne, P.d' (2008) Penser la Diversité du Monde, Seuil, Paris, France.

Jackson, T., Amaeshi, K. and Yavuz, S. (2008) 'Untangling African indigenous management: multiple influences on the success of SMEs in Kenya', Journal of World Business, Vol. 43, No. 4, pp.400-416.

Jamali, D., Karam, C., Yin, J. and Soundararajan, V. (2017) 'CSR logics in developing countries: translation, adaptation and stalled development', Journal of World Business, Vol. 52, No. 3, pp.343-359.

Jassawalla, A., Truglia, C. and Garvey, J. (2004) 'Cross-cultural conflict and expatriate manager adjustment: an exploratory study’, Management Decision, Vol. 42, No. 7, pp.837-849.

Johnson, C., Dowd, T.J. and Ridgeway, C.L. (2006) 'Legitimacy as a social process', Annual Review of Sociology, Vol. 32, No. 1, pp.53-78.

Kane, A.A. and Levina, N. (2017) 'Am I still one of them?: bicultural immigrant managers navigating social identity threats when spanning global boundaries', Journal of Management Studies, Vol. 54, No. 4, pp.540-577.

Keating, R.J. and Abramson, N.R. (2009) 'A new framework in the quest for cultural understanding using Australia, Thailand and Japan as an example', International Journal of Business Studies, Vol. 17, No. 1, pp.45-59.

Kennedy, E. and Adams, A. (1986) 'Carl Schmitt und die 'Frankfurter schule' Deutsche liberalismuskritik im 20 Jahrhundert', Geschichte und Gesellschaft, Vol. 12, No. 3, pp.380-419.

Key Differences (2018) Difference Between Invention and Innovation [online] http://www. keydifferences.com/difference-between-invention-and-innovation.html (accessed 7 July 2018).

Kitwood, T. (1986) 'Long waves in economic life: an image without a method', Journal of Interdisciplinary Economics, Vol. 1, No. 2, pp.107-125.

Kogut, B. and Singh, H. (1988) 'The effect of national culture on the choice of entry mode', Journal of International Business Studies, Vol. 19, No. 3, pp.411-432.

Kooijman, M., Hekkert, M.P., Meer, P.J.K. van Moors, E.H.M. and Schellekens, H. (2017) 'How institutional logics hamper innovation: the case of animal testing', Technological Forecasting and Social Change, Vol. 118, No. 1, pp.70-79. 
Kostova, T. and Zaheer, S. (1999) 'Organizational legitimacy under conditions of complexity: the case of the multinational enterprise', Academy of Management Review, Vol. 24, No. 1, pp.64-81.

Li, C., Brodbeck, F.C., Chenkar, O., Ponzi, L.J. and Fisch, J.H. (2017) 'Embracing the foreign: cultural attractiveness and international strategy', Strategic Management Journal, Vol. 38, No. 4, pp.950-971.

Li, J.J., Poppo, L. and Zhou, K.Z. (2010) 'Relational mechanisms, formal contracts, and local knowledge acquisition by international subsidiaries', Strategic Management Journal, Vol. 31, No. 4, pp.349-370.

López-Duarte, C., Vidal-Suárez, M.M. and González-Díaz, B. (2016) 'International business and national culture: a literature review and research agenda', International Journal of Management Reviews, Vol. 18, No. 4, pp.397-416.

Luo, Y. and Ho, S. (2001) 'Strategic alignment and performance of market-seeking MNCs in China', Strategic Management Journal, Vol. 22, No. 2, pp.141-155.

Martini, A., Neirotti, P. and Appio, F.P. (2017) 'Knowledge searching, integrating and performing: always a tuned trio for innovation?', Long Range Planning, Vol. 50, No. 2, pp.200-220.

Menkes, J. (1980) 'Justice and fairness in the technological order', Technological Forecasting and Social Change, Vol. 18, No. 1, pp.51-62.

Merriam-Webster (2018) Innovation [online] www.merriam-webster.com/dictionary/innovation (accessed 7 July 2018).

Miles, I. (2010) 'The development of technology foresight: a review', Technological Forecasting and Social Change, Vol. 77, No. 9, pp.1448-1456.

Munongo, B. (2011) La Diversité: Une Force Commune, Harmattan, Paris, France.

Oladottir, A.D., Hobdari, B., Papanastassiou, M., Pearce, R. and Sinani, E. (2012) 'Strategic complexity and global expansion: an empirical study of newcomer multinational corporations from small economies', Journal of World Business, Vol. 47, No. 4, pp.686-695.

Østergaard, C.R., Timmermans, B. and Kristinsson, K. (2011) 'Does a different view create something new? The effect of employee diversity on innovation', Research Policy, Vol. 40, No. 3, pp.500-509.

Parke, M.R. and Seo, M-G. (2017) 'The role of affect climate in organizational effectiveness', Academy of Management Review, Vol. 42, No. 2, pp.334-360.

Pietrobelli, C. and Puppato, F. (2016) 'Technology foresight and industrial strategy', Technological Forecasting and Social Change, Vol. 110, No. 1, pp.117-125.

Poesche, J., Igel, B. and Kauranen, I. (2017) 'Legitimation of innovation in a multipolar world', ELLTA Conference: Perspectives on Leadership, Learning and Social Enterprise in Asia, Bangkok, Thailand.

Prieto-Carrón, M., Lund-Thomsen, P. and Bhushan, C. (2006) 'Critical perspectives on CSR and development: what we know, what we don't know, and what we need to know', International Affairs, Vol. 82, No. 5, pp.977-987.

Quah, D. (2011) 'The global economy's shifting center of gravity', Global Policy, Vol. 2, No. 1, pp.3-9.

Redding, S.G. (1980) 'Relation to management processes: an exploratory view of Chinese case', Journal of Management Studies, Vol. 17, No. 2, pp.127-148.

Redding, S.G. (1994) 'Comparative management theory: jungle, zoo or fossil bed?', Organization Studies, Vol. 15, No. 3, pp.323-359.

Robinson, J.B. (1988) 'Unlearning and backcasting: rethinking some of the questions we ask about the future', Technological Forecasting and Social Change, Vol. 33, No. 4, pp.325-338.

Robinson, J.B. (1992) 'Of maps and territories: the use and abuse of socioeconomic modeling in support of decision making', Technological Forecasting and Social Change, Vol. 42, No. 2, pp.147-164. 
Rosenberg, N. and Frischtak, C.R. (1984) 'Technological innovation and long waves', Cambridge Journal of Economics, Vol. 8, No. 1, pp.7-24.

Ross, N. (2004) Culture \& Cognition: Implications to Theory and Method, Sage Publications, Thousand Oaks, CA.

Roy, J-L. (2014) Bienvenue Dans le Siècle de la Diversité, Stanké, Montréal, QC.

Schotter, A.P.J., Mudambi, R., Doz, Y.L. and Gaur, A. (2017) 'Boundary spanning in global organizations', Journal of Management Studies, Vol. 54, No. 4, pp.403-421.

Singh, J.V., Tucker, D.J. and House, R.J. (1986) 'Organizational legitimacy and the liability of newness', Administrative Science Quarterly, Vol. 31, No. 2, pp.171-193.

Song, S. (2017) 'Host market uncertainty, subsidiary characteristics, and growth option exercise', Long Range Planning, Vol. 50, No. 1, pp.63-73.

Suárez, H.J. (2006) 'Producción y transformación cultural', Sociológica, Vol. 21, No. 61, pp.235-256.

Suchman, M.C. (1995) 'Managing legitimacy: strategic and institutional approaches', Academy of Management Review, Vol. 20, No. 3, pp.571-610.

Suddaby, R. and Greenwood, R. (2005) 'Rhetorical strategies of legitimacy', Administrative Science Quarterly, Vol. 50, No. 1, pp.35-67.

Sulvarán López, J.L. and Ávila Romero, A. (2014) 'La idea de naturaleza entre los zoques de Chiapas: hacia la diversidad epistémica', Economía y Sociedad, Vol. 18, No. 30, pp.33-45.

Teagarden, M.B., Glinow, M.A. von Bowen, D.A., Frayne, C.A., Nason, S., Huo, Y.P., Milliman, J., Arias, M.E., Butler, M.C., Geringer, J.M., Kim, N-H., Scullion, H., Lowe, K.B. and Drost, E.A. (1995) 'Toward a theory of comparative management research: an idiographic case study of the best international human resources management project', Academy of Management Journal, Vol. 38, No. 5, pp.1261-1287.

Ting-Toomey, S., Gao, G., Trubisky, P., Yang, Z., Kim, H.S., Lin, S-L. and Nishida, T. (1991) 'Culture, face maintenance, and styles of handling interpersonal conflict: a study in five cultures', International Journal of Conflict Management, Vol. 2, No. 4, pp.275-96.

Tong, T.W. and Reuer, J.I. (2007) 'Real options in multinational corporations: organizational challenges and risk implications', Journal of International Business Studies, Vol. 38, No. 2, pp.215-230.

Vaara, E. and Tienari, J. (2008) 'A discursive perspective on legitimation strategies in multinational corporation', Academy of Management Review, Vol. 33, No. 4, pp.985-993.

van Beers, C. and Xand, F. (2014) 'R\&D cooperation, partner diversity, and innovation performance: an empirical analysis', Product Innovation Management, Vol. 31, No. 2, pp.292-312.

van Knippenberg, D. and Mell, J.N. (2016) 'Past, present, and potential future of team diversity research: from compositional diversity to emergent diversity', Organizational Behavior and Human Decision Processes, Vol. 136, No. 1, pp.135-145.

Varma, A. (2009) 'Chinese host country nationals' willingness to support expatriates: the role of collectivism, interpersonal affect and Guanxi', International Journal of Cross-cultural Management, Vol. 9, No. 2, pp.199-216.

Vergara, J.I., Gundermann, H. and Foerster, R. (2006) 'Legalidad y legitimidad: ley indígena, estado chileno y pueblos originarios (1989-2004)', Estudios Sociológicos, Vol. 24, No. 71, pp.331-361.

Veugelers, R. (2013) The World Innovation Landscape: Asia Rising?, Bruegel Policy Contribution, Brussels, Belgium.

Wallerstein, I. (2012) 'Paz, estabilidad y legitimidad, 1990-2025/2050', Argumentos, Vol. 25, No. 69, pp.59-77.

Wan, F., Williamson, P.J. and Yin, E. (2015) 'Antecedents and implications of disruptive innovation: evidence from China', Technovation, Vols. 39-40, No. 1, pp.94-104. 
Wilkinson, T.J., Peng, G.Z., Brouthers, L.E. and Beamish, P.W. (2008) 'The diminishing effect of cultural distance on subsidiary control', Journal of International Management, Vol. 14, No. 2 , pp.93-107.

Witchalls, P.J. (2012) 'Is national culture still relevant?', Interculture Journal, Vol. 11, No. 19, pp.11-18.

Yadong, L. and Tung, R.L. (2007) 'International expansion of emerging market enterprises: a springboard perspective', Journal of International Business Studies, Vol. 38, No. 4, pp.481-498.

Yang, J.Y., Lu, J. and Jiang, R. (2017) 'Too slow or too fast? Speed of FDI expansions, industry globalization, and firm performance', Long Range Planning, Vol. 50, No. 1, pp.74-92.

Zhao, E.Y., Fisher, G., Lounsbury, M. and Miller, D. (2017) 'Optimal distinctiveness: broadening the interface between institutional theory and strategic management', Strategic Management Journal, Vol. 38, No. 1, pp.93-113. 